\title{
Pengaruh Konsumsi Minuman Beralkohol terhadap Memori Harian pada Remaja dan Dewasa Awal
}

CHRISTINE DYANI \& ATIKA DIAN ARIANA*

Departemen Psikologi Klinis dan Kesehatan Mental, Fakultas Psikologi Universitas Airlangga

\begin{abstract}
ABSTRAK
Penelitian ini bertujuan untuk melihat pengaruh konsumsi minuman beralkohol terhadap memori harian pada remaja dan dewasa awal. Memori harian berisikan berbagai ingatan yang manusia gunakan untuk menjalani kegiatan sehari-hari. Metode penelitian ini menggunakan survei kuantitatif terhadap individu remaja dan dewasa awal. Jumlah partisipan dalam penelitian ini sebanyak 158 orang yang berusia 18-30an tahun dan mengonsumsi alkohol selama setidaknya 12 bulan terakhir. Pengumpulan data dilakukan dengan menggunakan kuesioner via Google Forms. Skala yang digunakan adalah Alcohol Use Disorder Identification Test (AUDIT) dan Everyday Memory Questionnaire (EMQ). Data dianalisis menggunakan analisis regresi linier sederhana. Hasil penelitian menunjukan konsumsi minuman beralkohol memiliki pengaruh yang positif dan signifikan terhadap memori harian pada remaja dan dewasa awal $\left(R^{2}=0.079 ; F(1156)=13,41 ; p<0,001\right)$. Terdapat pengaruh sebesar $7,9 \%$ dari konsumsi alkohol terhadap defisit memori harian. Semakin meningkatnya konsumsi minuman beralkohol, semakin meningkat risiko kegagalan dan defisit pada memori harian.
\end{abstract}

Kata kunci: alkohol, dewasa awal, memori harian, remaja

\section{ABSTRACT}

This study aims to determine the effect of alcohol consumption on everyday memory in adolescents and early adulthood. Everyday memory contains various memories that humans use to carry out their daily life. This research method uses quantitative survey. The number of participants was 158 people aged 18-30 years old and have been consumed alcohol for at least the last 12 months. Data collection was carried out using a questionnaire via Google Forms. The scales used are the Alcohol Use Disorder Identification Test (AUDIT) and the Everyday Memory Questionnaire (EMQ). Data were analyzed using simple linear regression analysis. The result showed that alcohol consumption had a positive and significant effect on everyday memory in adolescents and early adulthood $\left(R^{2}=0,079\right.$; $F(1,156)=13,41 ; p<0,001)$. There is influence of $7.9 \%$ from alcohol consumption to everyday memory deficit. The increasing consumption of alcohol, the higher the risk of failure and deficit in everyday memory.

Keywords: adolescents, alcohol, early adulthood, everyday memory

Buletin Penelitian Psikologi dan Kesehatan Mental (BRPKM), 2021, Vol. 1(no), 59-67

*Alamat korespondensi: Fakultas Psikologi Universitas Airlangga, Kampus B Universitas Airlangga Jalan Airlangga 4-6 Surabaya 60286. Surel: atika.ariana@psikologi.unair.ac.id 
sehingga penggunaan, distribusi, reproduksi dalam media apapun atas artikel ini tidak dibatasi, selama sumber aslinya disitir dengan baik.

\section{P E N D A H U L U A N}

Kehidupan manusia tidak dapat dipisahkan dengan ingatan atau yang kerap disebut memori. Memori memiliki peran penting dalam kehidupan manusia. Berbagai peristiwa maupun hal penting lainnya terdapat pada memori yang berpusat di otak. Memori atau yang sering disebut ingatan, merupakan salah satu kemampuan penting yang dimiliki manusia. Kemampuan untuk mengingat kejadian maupun peristiwa masa lampau serta membawa kembali fakta dan gagasan yang sudah dipikirkan sering dianggap sebagai pengertian dari memori. Pada dasarnya memori adalah cara seseorang untuk mempertahankan dan memanfaatkan peristiwa yang sudah lewat atau lampau dan digunakan sebagai informasi di masa sekarang (Tulving \& Craik, 2000). Memori harian yang kerap digunakan di dunia nyata merupakan memori yang digunakan manusia untuk menjalani kehidupan. Memori harian atau yang kerap disapa everyday memory terkait dengan konteks, berbagai ingatan dalam kehidupan sehari hari seperti, mengingat daftar belanjaan, mengingat untuk menelpon teman atau kerabat, mengisi bensin, menceritakan plot drama di televisi, dan mengingat tagihan yang harus dibayar merupakan contoh dari memori harian. Saat dimana seseorang mampu mengingat rincian dari sebuah peristiwa, pemulihan aspek konteks seperti adegan akan terjadi. Hal tersebut mampu untuk mendukung retrieval atau proses pengingatan kembali (Cohen \& Conway, 2008).

Disfungsi dari memori dapat disebabkan karena berbagai hal, pada sudut pandang kognitif disfungsi memori dapat diulas dengan neuropsikologi dan neuropsikiatri. Kognitif neuropsikologi yang terganggu dikarenakan kerusakan pada otak dan disfungsi fisiknya seperti stroke, cedera kepala maupun kematian sel merupakan penyebab dari disfungsi pada memori. Sedangkan pada kognitif neuropsikiatri, keadaan seperti depresi, post traumatic stress disorder, dan skizofrenia belum terlalu dapat menjelaskan dampaknya pada disfungsi memori (Cohen \& Conway, 2008). Penelitian ini memfokuskan gangguan memori yang disebabkan oleh buruknya neuropsikologi manusia akibat mengonsumsi minuman beralkohol. Kondisi otak pada individu rentang usia remaja dan dewasa awal rentan terkena efek neurotoksik dari alkohol (Carbia dkk., 2017). Perkembangan pesat baik dari sisi biologis, kognitif, dan sosioemosional menjadikan rentang usia remaja dan dewasa awal menjadi masa dimana seseorang kerap tidak stabil dikarenakan berbagai masalah yang dihadapi. Konsumsi minuman beralkohol pada usia remaja dan dewasa awal mampu mempengaruhi kerusakan pada otak sehingga menimbulkan kemunduran dari fungsi dan kinerja memori (Wardah \& Surjaningrum, 2013).

Kebiasaan meminum alkohol pada orang dewasa sudah menjadi hal yang cukup wajar walaupun pada umumnya kebiasaan tersebut bukanlah budaya orang Indonesia. Peraturan Menteri Perdagangan bernomor 20/M-DAG/PER/4/2014 menyatakan bahwa hanya konsumen berusia 21 tahun atau lebih yang dapat membeli minuman beralkohol golongan A dengan kadar alkohol maksimal lima persen seperti bir dengan menunjukan KTP terlebih dahulu. Meskipun negara mengizinkan pembelian minuman beralkohol pada usia 21 tahun atau lebih, tidak jarang remaja dan dewasa awal dengan usia 21 tahun kebawah sudah mengonsumsi alkohol dan melanggar peraturan pemerintah (Lestari, 2016). Beberapa daerah di Indonesia menunjukan terjadi peningkatan dalam mengonsumsi minuman beralkohol menurut Riset Kesehatan Dasar (RISKESDAS) milik Kementerian Kesehatan Republik Indonesia. Data menunjukan terjadi peningkatan yang cukup signifikan pada tahun 2017 dan 2018 di Sulawesi Utara, Nusa Tenggara Timur, Bali, Gorontalo, dan Maluku (Badan Penelitian dan Pengembangan Kesehatan (Badan Litbangkes) Kementerian Kesehatan Republik Indonesia, 2018). 
Motif mengonsumsi minuman beralkohol bagi orang dengan usia dewasa awal ada tiga. Ketiga motif tersebut adalah motif sosial, motif coping, dan motif enhancement (penguatan atau peningkatan). Terdapat tiga variabel yang menjadi tiga prediktor umum dalam menjelaskan tiga motif dari minum minuman beralkohol. Ketiga variabel diantaranya adalah pengguna alkohol remaja, banyaknya teman yang juga menggunakan alkohol, dan berjenis kelamin laki-laki. Ketiga motif yaitu sosial, coping, dan enhancement memiliki hubungan yang cukup signifikan dengan dua prediktor yakni, remaja pengguna alkohol dan banyaknya teman yang menggunakan alkohol (Windle \& Windle, 2018). Remaja di Indonesia yang kerap mengonsumsi minuman beralkohol atau menyalahgunakannya dipengaruhi oleh beberapa faktor. Penelitian (Rori, 2015) menyimpulkan bahwa remaja di Sulawesi Utara mengonsumsi alkohol dipengaruhi oleh faktor individu, faktor lingkungan, faktor keluarga, faktor agama, dan faktor pendidikan.

Faktor individu menjadi faktor yang dominan sebagai alasan mengapa remaja mengonsumsi alkohol, alasan seperti meringankan masalah, pelarian dari beban, ingin terlihat berani di depan teman sebaya, dan mencoba hal baru untuk membayar rasa penasaran menjadi hal yang paling sering terjadi. Faktor keluarga seperti masalah yang terjadi dalam keluarga, komunikasi yang kurang harmonis antar orang tua dan anak, serta berbagai hal lain yang terjadi dalam keluarga dapat mendorong anak untuk mengonsumsi alkohol sebagai solusi dari masalah yang dialami. Faktor lingkungan juga dapat menyebabkan meningkatnya konsumsi alkohol pada remaja. Berbagai alasan seperti lingkungan yang kurang baik, ketersediaan minuman keras di lingkungan, perasaan setia kawan dan alasan lainnya menjadi faktor lingkungan seseorang dalam mengonsumsi alkohol.

Agama juga menjadi faktor dari konsumsi alkohol pada remaja di Indonesia, pembimbingan orang tua dalam mendidik anaknya untuk beragama mampu membentuk keperibadian remaja tersebut untuk memilih mana yang baik dan buruk bagi diri sendiri dan orang lain. Selain keempat faktor yang sudah disebutkan, pendidikan juga menjadi faktor dari seseorang mengonsumsi alkohol. Cara berpikir seseorang untuk menilai mana yang baik dan buruk serta pertimbangan berbagai keputusan dan risiko tergantung dari kualitas sumber daya manusia berdasarkan tingkat pendidikan yang dimiliki, yang nantinya membantu seseorang untuk bijak dalam memilih untuk mengonsumsi alkohol atau tidak (Rori, 2015).

Masa dewasa awal merupakan masa perkembangan dimana seseorang sedang menata kehidupan dan kerap melakukan pemilihan jalan hidup. Individu di rentang usia ini rentan memilih pola hidup yang tidak sehat sebagai gaya hidup pribadi. Seperti menghiraukan waktu sarapan, merokok, tidak berolahraga, mengonsumsi alkohol dan berbagai perilaku tidak sehat lainnya. Alasan seperti pencarian kesenangan ataupun pulih dari stress yang dialami kerap menjadi alasan bagi dewasa awal yang memilih untuk mengonsumsi alkohol (Utina, 2012).

Berbagai dampak dari konsumsi minuman alkohol mampu meningkatkan konsekuensi berbahaya dalam aspek fisik, mental, dan sosial (Babor dkk., 2001). Beberapa penelitian terdahulu menunjukan berbagai dampak alkohol pada bagian otak manusia. Hasil dari sebuah penelitian menunjukan bahwa konsumsi minuman beralkohol dapat mempengaruhi banyaknya kegagalan kognitif pada memori harian, Defisit dari memori harian yang disebabkan oleh konsumsi minuman beralkohol dalam jumlah yang banyak mampu mempengaruhi performa kognitif seseorang (Ling dkk., 2003). Penelitian lainnya menunjukan bahwa usia remaja dan dewasa awal merupakan dua golongan usia yang rentan terhadap efek alkohol. Individu pada usia tersebut dengan penggunaan konsumsi alkohol yang cukup intens dapat menyebabkan terjadinya defisit pada working memory dikarenakan terjadi gangguan khususnya pada prefrontal cortex (Carbia dkk., 2017). Etanol maupun alkohol dengan dosis yang cukup besar dan 
memabukkan mampu mengganggu proses belajar dan memori dengan merubah bagian sirkuit otak tertentu. Paparan alkohol secara akut dapat mengubah fungsi saraf tertentu tergantung dengan dosis dan wilayah pada otak. Adapun bagian-bagian otak tertentu yang terganggu bila terpapar oleh alkohol secara akut yaitu, hippocampus, cerebellum, dan amygdala. Pada bagian hippocampus terjadi hambatan pada spatial working memory, contextual learning, dan spontaneous alternation. Sedangkan untuk bagian cerebellum terjadi gangguan pada pengkondisian kedipan mata dan depresi jangka panjang tergantung dengan kadar alkohol tertentu.

Berbeda lagi dengan bagian amygdala, pada amygdala terjadi gangguan pada pengkondisian isyarat serta emotional memory recall (Van Skike, Goodlett, \& Matthews, 2019). Alkohol juga dapat mempengaruhi berkurangnya grey matter volume pada otak. Hal tersebut akhirnya berdampak pada memori, pelajaran verbal, proses visuospasial, dan atensi. Berbeda dengan dewasa, remaja yang terkena paparan alkohol dengan jumlah tertentu memiliki gangguan pada neurotransmitter sehingga menjadi sangat rentan. Fungsi neurotransmitter sangatlah penting dalam mengelola segala fungsi yang terjadi di otak, sehingga apabila terjadi gangguan pada bagian tersebut tentunya akan menghambat cara kerja otak (Spear, 2018). Menurut DSM V, konsumsi minuman beralkohol dengan intensitas dan dosis tertentu dalam jangka waktu yang panjang dapat menyebabkan kerusakan memori parah dan berujung pada kelainan amnestik yaitu sindrom Wemicke-Korsakoff.

\section{Desain Penelitian}

\section{MET O D E}

Penelitian ini menggunakan pendekatan kuantitatif dengan tipe survei. Data dikumpulkan dengan menggunakan kuesioner dan disebarkan secara daring melalui media Google Forms. Kuesioner dibagi menjadi data demografis, Alcohol Use Disorder Identification Test untuk mengukur konsumsi minuman beralkohol, dan Everyday Memory Questionnaire untuk mengukur defisit memori harian. Validitas dari alat ukur menggunakan professional judgement. Pengukuran reliabilitas menggunakan Alpha Cronbach. Analisis data yang digunakan adalah regresi linier sederhana dengan menggunakan software IBM SPSS Statistic 22 for Windows. Analisis data digunakan dengan tujuan untuk melihat pengaruh dari konsumsi minuman beralkohol terhadap memori harian pada remaja dan dewasa awal.

\section{Partisipan}

Partisipan pada penelitian ini memiliki kriteria individu dengan rentang usia 18-30 tahun dan mengonsumsi alkohol selama setidaknya 12 bulan terakhir. Teknik sampling yang digunakan pada penlitian ini adalah purposive sampling. Purposive sampling merupakan teknik pengambilan sampel dengan menentukan penilaian atau kriteria tertentu yang sesuai dengan tujuan penelitian (Neuman, 2014). Jumlah sampel minimal untuk melakukan uji regresi adalah sebanyak 15 sampai dengan 20 kali dari total variabel yang diteliti. Penelitian ini menggunakan dua variabel, maka jumlah sampel minimal adalah sebanyak 30 sampai 40 sampel (Hair Jr., Black, Babin, \& Anderson, 2014). Jumlah partisipan yang terkumpul pada penelitian ini adalah 158 partisipan. Partisipan diminta untuk mencermati pernyataan persetujuan dalam pengambilan data sebelum mengisi kuesioner penelitian ini dan memberikan pernyataan setuju atau tidak untuk menjadi partisipan dalam penelitian ini.

Pengujian hipotesis pada penelitian ini menggunakan data dari 158 partisipan $\left(M_{\text {usia }}=21,9 ; S D_{\text {usia }}=2,56\right.$; 58,2 persen laki laki dan 41,8 persen perempuan). Partisipan berasal dari 26 kota di Indonesia. Partisipan dengan latar belakang pelajar atau mahasiswa berjumlah 106 orang (67\%), partisipan yang bekerja sebanyak 39 orang $(24,8 \%)$, dan partisipan yang sedang tidak bekerja sebanyak 13 orang $(8,2 \%)$. 


\section{Pengukuran}

Pengukuran pada penelitian ini menggunakan skala milik World Health Organization (WHO) yaitu Alcohol Use Disorder Identification Test (AUDIT) untuk mengukur variabel konsumsi alkohol. Skala AUDIT berjumlah 10 aitem. Versi yang digunakan pada penelitian ini adalah versi self report dalam Bahasa Indonesia. Skala AUDIT memiliki koefisien Cronbach's alpha sebesar $\alpha=0,860$. Variabel memori harian diukur dengan menggunakan skala Everyday Memory Questionnaire (EMQ) milik Sunderland, Harris, dan Baddeley yang berjumlah 28 aitem. Skala EMQ merupakan skala yang berisikan kegagalankegagalan yang terjadi pada memori harian. Skala yang digunakan berbahasa Indonesia. Pilihan jawaban pada skala ini terdiri dari 4 pilihan jawaban $(0=$ "Tidak pernah dalam sebulan terakhir", 1="Sekitar 1-3 kali dalam sebulan",2="Sekitar 1-3 kali dalam seminggu",3="Lebih dari 3 kali dalam seminggu"). Reliabilitas pada skala EMQ cukup baik $(\alpha=0,861)$. Validitas pada kedua alat ukur menggunakan professional judgement peneliti sebelumnya yakni (Nanuru, 2018) dan (Muhammad, Afifah, \& Gayatri, 2019).

Skor didapatkan dengan cara dijumlahkan. Uji asumsi yang dilakukan yaitu uji normalitas residual, uji linearitas, uji homokedastisitas, dan uji korelasi. Data yang diperolah berdistribusi normal dengan nilai Kolmogorov Smirnov sebesar 0,2. Data memiliki hubungan yang linier dengan nilai linearity sebesar 0,0 dan deviation from linearity sebesar 0,057. Selain itu, data tidak memiliki gejala heterokedastisitas. Kedua variabel memiliki korelasi dengan nilai uji product moment pearson sebesar 0,0.

\section{Analisis Data}

Uji regresi linier sederhana dilakukan menggunakan software IBM SPSS Statistic 22 for Windows. Peneliti juga melakukan uji komparasi mean berdasarkan data demografis yang didapatkan dari masing-masing partisipan. Selain itu, peneliti melakukan uji regresi berganda sebagai tambahan informasi untuk melihat dimensi dari variabel memori harian mana yang lebih terpengaruh oleh variabel konsumsi minuman beralkohol.

\section{HAS I L P EN ELITIAN}

Hasil dari uji analisis deskriptif menunjukan jumlah partisipan sebanyak 158 menghasilkan skor terendah (Min) pada variabel konsumsi alkohol sebesar 0 dan variabel memori harian sebesar 0 . Skor tertinggi (Max) pada variabel konsumsi alkohol memiliki nilai sebesar 29, dan variabel memori harian sebesar 38. Nilai rata-rata (Mean) pada variabel konsumsi alkohol sebesar 7,37 dan pada variabel memori harian sebesar 14,57. Berdasarkan data yang didapatkan, sebanyak 64 partisipan memasuki kategori sedang dalam masalah penggunaan alkohol (40,5\%), dan sebanyak 3 orang masuk kedalam kategori tinggi dalam masalah penggunaan alkohol dan butuh di diagnosa lebih lanjut terkait masalah ketergantungan alkohol (1,9\%). Pada variabel memori harian, sebanyak 143 partisipan dikategorikan rendah (90,5\%), dan sebanyak 15 partisipan dikategorikan sedang (9,5\%). Kategori rendah pada variabel memori harian memiliki pengertian bahwa individu memiliki kualitas memori harian yang cukup baik dikarenakan skala EMQ merupakan skala yang mengukur kegagalan-kegagalan memori harian.

Hasil dari analisis korelasi dengan product moment pearson menunjukan adanya korelasi antara variabel konsumsi minuman beralkohol dan memori harian pada remaja dan dewasa awal $(\mathrm{r}(158)=0,28 ; p=<0,001)$. Uji komparasi mean berdasarkan data demografis terdiri dari usia, jenis kelamin, domisili, dan kesibukan yang sedang dijalani. Hasil dari uji komparasi mean berdasarkan 14 golongan usia yang menggunakan one-way ANOVA, terdapat perbedaan rata-rata signifikan pada 
variabel memori harian $(F(13,144)=2,45 ; p<0,001)$ dan tidak terdapat perbedaan rata-rata pada variabel konsumsi alkohol $(F(13,144)=0,79 ; p>0,001)$. Uji komparasi mean berdasarkan jenis kelamin menggunakan independent sample t-test menunjukan tidak terdapat perbedaan rata-rata pada variabel memori harian $(t(156)=-1,56 ; p>0,001)$ dan terdapat perbedaan rata-rata pada variabel konsumsi alkohol $(t(156)=2,08 ; p<0,001)$. Laki-laki $(M=8,12 ; S D=5,9)$ memiliki skor konsumsi alkohol yang lebih tinggi dibandingkan perempuan $(M=6,33 ; S D=4,27)$. Uji komparasi rata-rata berdasarkan 26 golongan domisili menggunakan one-way ANOVA, menunjukan tidak terdapatnya perbedaan rata-rata pada variabel memori harian $(F(25,132)=1,60 ; p>0,001)$ dan terdapat perbedaan rata-rata pada variabel konsumsi minuman beralkohol $(F(25,132)=1,03 ; p<0,001)$. Uji komparasi rata-rata berdasarkan kesibukan yang sedang dijalani yaitu sekolah/kuliah, bekerja, dan sedang tidak bekerja dilakukan menggunakan one-way ANOVA, menunjukan tidak terdapatnya perbedaan rata-rata pada variabel memori harian $(F(2,155)=0,65 ; p>0,001)$ dan tidak terdapatnya perbedaan rata-rata pada variabel konsumsi alkohol $(F(2,155)=0,59 ; p>0,001)$.

Analisis regresi menunjukan adanya pengaruh positif yang signifikan dari konsumsi alkohol terhadap memori harian $\left(R^{2}=0,079 ; F(1,156)=13,41 ; p<0,001\right)$. Konsumsi minuman beralkohol secara signifikan mampu memprediksi memori harian $(B=0,28 ; p<0,001)$. Peneliti juga melakukan analisis regresi berganda sebagai informasi tambahan. Analisis regresi berganda dilakukan dengan memisahkan tiap dimensi dari variabel memori harian. Dimensi pemantauan percakapan atau conversational monitoring merupakan dimensi yang signifikan terdampak dikarenakan konsumsi alkohol $\left(R^{2}=0,089 ; F(1,156)=15,26 ; p<0,001\right)$ dan dimensi memory for activities merupakan dimensi yang tidak terlalu signifikan terdampak dikarenakan konsumsi alkohol $\left(R^{2}=0,025 ; F(1,156)=4,04 ; p<0,001\right)$.

\section{I S K U S I}

Hasil penelitian uji analisis regresi linier sederhana, konsumsi minuman beralkohol memiliki pengaruh terhadap memori harian. Temuan ini diperkuat dengan penelitian terdahulu yang dilakukan, yang menemukan bahwa individu yang memiliki ketergantungan terhadap zat alkohol akan mengalami gangguan performa, khususnya pada beberapa fungsi penting dari memori harian (Ling dkk., 2003). Seperti memori kerja umum, memori jangka panjang dan pendek yang bersifat logis dapat terganggu cara kerjanya bila terpengaruh oleh penggunaan alkohol berlebih. Penggunaan alkohol dalam skala berat mampu mempengaruhi kognitif harian dalam mengalami penurunan kinerja. Hasil dari penelitian menunjukan semakin banyak alkohol yang dikonsumsi, semakin banyak pula kegagalan kognitif dalam keseharian. Defisit kognitif yang didukung dengan buruknya kinerja memori harian mampu merugikan individu yang mengonsumsi alkohol dalam skala berat bila dibandingkan dengan individu yang mengonsumsi dengan skala sedikit atau tidak mengonsumsi sama sekali. Masalah kognitif yang dialami oleh pengguna alkohol dalam skala besar mampu diobservasi dalam kehidupan sehari-harinya (Ling dkk., 2003).

Remaja yang mengonsumsi minuman beralkohol mampu mengganggu atensi, proses visuospasial dan memori, serta terhambatnya pertumbuhan grey matter pada otak. Penelitian menunjukan tingginya konsumsi minuman beralkohol perhari pada remaja tidak sebanding dengan dewasa, namun ketika hal tersebut berkaitan dengan volume minuman yang dikonsumsi, remaja mengonsumsi dalam skala yang lebih banyak dan berat bila dibandingkan dengan dewasa. Pada remaja, terjadi reduksi grey matter dikarenakan konsumsi minuman beralkohol. Memburuknya keadaan kognitif, defisit beberapa fungsi di otak, dan meningkatnya impulsivitas menjadi dampak buruk yang disebabkan dari mengonsumsi alkohol pada usia remaja. Pada neurotransmitter juga terjadi gangguan dan hal tersebut penting perannya dalam kognitif dari memoi dan belajar (Spear, 2018). Pengaruh dari mengonsumsi minuman 
beralkohol mempengaruhi kegiatan pembelajaran dan memori. Bagian-bagian otak yang mengatur memori seperti amygdala, hippocampus, cerebellum, volume grey matter dapat mengalami penurunan fungsi dikarenakan zat alkohol.

Pada taraf konsumsi alkohol akut, perubahan pada berbagai bagian dari memori dapat mengalami gangguan: mulai dari working memory, visuospatial working memory, kemampuan recall, prospective memory, serta bagian lainnya dapat terjadi defisit yang berujung gangguan (Van Skike dkk., 2019).

Seseorang dapat dikatakan telah melakukan binge drinking ketika mengonsumsi alkohol melebihi jumlah x dan mengarah ke intoksikasi, dan sebuah pola dari mengonsumsi alkohol dalam skala berat diluar dari kebutuhan klinis serta mengarah ke penyalahgunaan dan ketergantungan. Dalam hal ini jumlah yang ditentukan adalah mengonsumsi 5 minuman atau lebih dalam satu waktu (E. Kuntsche dkk., 2004). Berdasarkan hasil dari kuesioner AUDIT pada penelitian ini, aitem nomor 3 yang berisi "Seberapa sering anda minum 6 atau lebih takaran minuman beralkohol dalam satu waktu?", sebanyak 40 responden menjawab tidak pernah, sebanyak 58 responden menjawab kurang dari sebulan (36,7\%), sebanyak 38 responden menjawab setiap bulan (24,1\%), sebanyak 15 responden menjawab setiap minggu (9,5\%), dan sebanyak 7 responden menjawab setiap hari atau hampir setiap hari $(4,4 \%)$. Hal tersebut menggambarkan bahwa mayoritas subjek pernah melakukan binge drinking selama setidaknya kurang dari sebulan hingga yang paling sering adalah setiap hari atau hampir setiap hari.

Individu yang berada pada usia remaja dan dewasa awal mempunyai kerentanan dari neurotoksik dari alkohol. Efek dari mengonsumsi alkohol terhadap daya ingat keseharian adalah saat terjadinya defisit pada working memory. Hal tersebut dilihat dari hasil penelitian menggunakan kuesioner AUDIT khususnya aitem nomor 3 yang memang mengarah ke heavy drinking atau binge drinking. Pada penelitian menunjukan bahwa subjek yang merupakan rentang usia remaja dan dewasa awal yang secara stabil dan cukup rutin dalam melakukan binge drinking berasosiasi dengan buruknya kinerja working memory. Sehingga hal tersebut mempengaruhi lemahnya proses kognitif dimana pada usia tersebut benar-benar dibutuhkan (Carbia dkk., 2017). Individu yang sedang berada di bangku pendidikan seperti sekolah ataupun kuliah menduduki jumlah terbesar dari sebaran responden pada penelitian ini. Efek dari konsumsi minuman beralkohol pada skala berat dan berbahaya pada individu dengan kesibukan sekolah atau kuliah berpengaruh pada semakin berkurangnya volume dari grey matter dan hippocampus. Semakin mengecilnya volume dari hippocampus mempengaruhi buruknya kinerja memori dan semakin meningkatnya blackouts memori. Hal tersebut yang nantinya berdampak pada pencapaian akademik yang dijalani di kampusnya. Kesuksesan dalam perkuliahan dan kualitas hidup di usia dewasa awal dapat dipengaruhi oleh semakin beratnya skala dalam mengonsumsi alkohol, seiring dengan buruknya performa akademik secara neurobiologis (Meda dkk., 2018).

\section{S I M P U L A N}

Hasil analisis statistik yang sudah dilakukan pada penelitian ini, mendukung kesimpulan bahwa kosumsi minuman beralkohol memiliki pengaruh yang signifikan terhadap memori harian pada subjek rentang usia remaja dan dewasa awal. Konsumsi minuman beralkohol berpengaruh terhadap kegagalan-kegagalan yang terjadi pada memori harian. Semakin seseorang sering mengonsumsi minuman beralkohol, semakin beresiko mengalami gangguan pada memori harian. 


\section{U CAPAN TERIMAKASIH}

Saya ucapkan terima kasih kepada Tuhan Yesus Kristus, keluarga, dan seluruh teman-teman yang tidak henti-hentinya mendukung dan menyemangati saya selama penelitian ini berlangsung hingga selesai. Serta, terima kasih kepada peneliti terdahulu yang sudah memberikan saya alat ukur dan izin untuk menggunakannya sehingga memudahkan proses penelitian ini.

\section{DEKLARASI POTENSI TERJADINYA KONFLIK KEPENTINGAN}

Christine Dyani dan Atika Dian Ariana tidak bekerja, menjadi konsultan, memiliki saham, atau menerima dana dari perusahaan atau organisasi manapun yang mungkin akan mengambil untung dari diterbitkannya naskah ini.

\section{PUSTAKA ACUAN}

Babor, T. F., Higgins-biddle, J. C., Saunders, J. B., Monteiro, M. G., Higgins-biddle, J. C., Saunders, J. B., \& Monteiro, M. G. (2001). The Alcohol Use Disorders Identification Test.

Badan Penelitian dan Pengembangan Kesehatan (Badan Litbangkes) Kementerian Kesehatan Republik Indonesia. (2018). RISKESDAS 2018. Jakarta: Kementerian Kesehatan Republik Indonesia.

Carbia, C., Cadaveira, F., López-Caneda, E., Caamaño-Isorna, F., Rodríguez Holguín, S., \& Corral, M. (2017). Working memory over a six-year period in young binge drinkers. Alcohol, 61, 17-23. https://doi.org/10.1016/j.alcohol.2017.01.013

Cohen, G., \& Conway, M. A. (2008). Memory in the real world. New York: Psychology Press.

Hair Jr., J. F., Black, W. C., Babin, B. J., \& Anderson, R. E. (2014). Multivariate Data Analysis Pearson New International Edition (7th ed.). Harlow: Pearson Education Limited.

Kuntsche, E., Rehm, J., \& Gmel, G. (2004). Characteristics of binge drinkers in Europe. Social Science and Medicine, 59(1), 113-127. https://doi.org/10.1016/j.socscimed.2003.10.009

Lestari, T. R. P. (2016). MENYOAL PENGATURAN KONSUMSI MINUMAN BERALKOHOL DI INDONESIA Questioning the Regulation on Consumption of Alcoholic Beverages in Indonesia. Aspirasi, (86), 127-141.

Ling, J., Heffernan, T. M., Buchanan, T., Rodgers, J., Scholey, A. B., \& Parrott, A. C. (2003). Effects of alcohol on subjective ratings of prospective and everyday memory deficits. Alcoholism: Clinical and Experimental Research, 27(6), 970-974. https://doi.org/10.1097/01.ALC.0000071741.63467.CB

Meda, S. A., Hawkins, K. A., Dager, A. D., Tennen, H., Khadka, S., Austad, C. S., ... Pearlson, G. D. (2018). Longitudinal Effects of Alcohol Consumption on the Hippocampus and Parahippocampus in College Students. Biological Psychiatry: Cognitive Neuroscience and Neuroimaging, 3(7), 610-617. https://doi.org/10.1016/j.bpsc.2018.02.006 
Muhammad, F., Afifah, E., \& Gayatri, D. (2019). The relationship between sleep quality and lack of memory in Universitas Indonesia students The Relationship between Sleep Quality and Lack of Memory in Universitas Indonesia Students. 040017(April). https://doi.org/10.1063/1.5096750

Nanuru, J. N. (2018). Pengaruh stres terhadap penyalahgunaan alkohol pada dewasa awal. (2001), 1-10.

Neuman, W. L. (2014). Social Research Methods: Qualitative and Quantitative Approaches. In Teaching Sociology (Vol. 30). Harlow: Pearson Education Limited. https://doi.org/10.2307/3211488

Rori, P. L. P. (2015). PENGARUH PENGGUNAAN MINUMAN KERAS PADA KEHIDUPAN REMAJA DI DESA KALI KECAMATAN PINELENG KABUPATEN MINAHASA. Holistik, 16(16), 1-12. Retrieved from http://download.portalgaruda.org/article.php?article=70988\&val=4882

Spear, L. P. (2018). Effects of adolescent alcohol consumption on the brain and behaviour. Nature Reviews Neuroscience, 19(4), 197-214. https://doi.org/10.1038/nrn.2018.10

Tulving, E., \& Craik, F. M. (2000). The Oxford Handbook of Memory. Toronto: Oxford University Press.

Utina, S. S. (2012). Alkohol dan Pengaruhnya Terhadap Kesehatan Mental. Jurnal Health and Sport, 5(2), $1-11$.

Van Skike, C. E., Goodlett, C., \& Matthews, D. B. (2019). Acute alcohol and cognition: Remembering what it causes us to forget. Alcohol, 79, 105-125. https://doi.org/10.1016/j.alcohol.2019.03.006

Wardah, F. R., \& Surjaningrum, E. R. (2013). Pengaruh Ekspektansi pada Minuman Beralkohol terhadap Konsumsi Minuman Beralkohol. Jurnal Psikologi Klinis Dan Kesehatan Mental, 2(Agustus), 96-102. Retrieved from http://www.eskom.co.za/CustomerCare/TariffsAndCharges/Documents/RSA Distribution Tariff Code Vers 6.pdf\%0Ahttp://www.nersa.org.za/

Windle, R. C., \& Windle, M. (2018). Adolescent precursors of young adult drinking motives. Addictive Behaviors, 82, 151-157. https://doi.org/10.1016/j.addbeh.2018.03.002 